\title{
ANALISIS PERBANDINGAN PETA KEMAMPUAN KEUANGAN DAERAH PENGHASIL SDA DAN NON-SDA DI ERA DESENTRALISASI FISKAL
}

\author{
(Comparative Analysis of Regional Financial Mapping \\ from The Producer of Natural Resources and Non-Natural Resources \\ in The Fiscal Decentralization Era)
}

\author{
Joko Tri Haryanto ${ }^{1}$ \\ ${ }^{1}$ Pusat Kebijakan Pembiayaan Perubahan Iklim dan Multilateral \\ Badan Kebijakan Fiskal, Kementerian Keuangan \\ Jl. Dr. Wahidin Raya, Jakarta Pusat, 10710. \\ Email: Djohar78@gmail.com \\ Naskah diterima: 10 Juli 2017 \\ Naskah direvisi: 03 Agustus 2017 \\ Naskah diterbitkan:31 Desember 2017
}

\begin{abstract}
Mapping the ability of local finance is very important to see the level of regional independence in exercising its authority. In some cases, locally weak generated revenue as well as large expenditure cause a low level of regional self-sufficiency. This regional independency is also affected by regional conditions, which varies widely. For instances, some areas are natural resource producers, and some are classified as non-natural resources producers but still have large tax basis. While most other areas just do not have any wealth resources. With such varied conditions, it would require a comprehensive analysis of national policy making while taking into account the characteristics of each region. Unfortunately, there are very few researches have been conducted, which based on the characteristics of the area. For this reason and in the initial phase, this study focuses on the analysis by comparing between natural resource and non-natural resources producer. The research applies quadrant method with share and growth analysis approach from each region. From the result of the share analysis, it is concluded that the area of natural resources producer has a higher value than the non-natural resources area. In contrast to growth analysis, non-natural resource area have a higher value than natural resource producer. From quadrant method analysis, only Badung regency that can be clasified into quadrant I. All non-natural resource producers area enter into quadrant II, while the entire region of natural resource producer enters into quadrant III minus Indragiri Hilir regency. Within the quadrant IV, from all research locus there is only Indragiri Hilir Regency. Based on these results, the government must focus the policy of Fund Transfer to the areas that are located in quadrant IV.

Keywords: natural resource producer, quadrant method, share, growth
\end{abstract}

\begin{abstract}
Abstrak
Pemetaankemampuankeuangan daerahsangatpenting untukmelihattingkatkemandirian daerah dalammenjalankankewenangannya. Dalam beberapa kasus, rendahnya kemandirian daerah, selain disebabkan oleh lemahnya penerimaan PAD juga disebabkan oleh beban pengelolaan belanja APBD yang besar. Di sisi lain, kondisi daerah di Indonesia sangat bervariasi. Beberapa daerah merupakan penghasil SDA dan beberapa lainnya tergolong non-SDA namun memiliki basis pajak yang besar. Sementara sebagian besar daerah lainnya justru tidak memiliki kekayaan apapun. Dengan kondisi yang sangat bervariasi tersebut, tentu dibutuhkan sebuah analisis yang komprehensif dalam pengambilan kebijakan secara nasional dengan tetap memerhatikan karakteristik masing-masing daerah. Sayangnya, penelitian dengan mendasarkan karakteristik daerah tersebut belum banyak dilakukan. Untuk itulah di tahap awal, kajian ini memfokuskan analisis pada perbandingan daerah penghasil SDA dan non-SDA. Metode penelitian yang digunakan adalah metode kuadran dengan pendekatan analisis share dan growth dari masing-masing daerah. Dari hasil analisis share, disimpulkan bahwa daerah penghasil SDA memiliki nilai yang lebih besar dibandingkan daerah non-SDA. Sebaliknya dari analisis growth, daerah non-SDA memiliki nilai lebih besar dibandingkan daerah penghasil SDA. Dari analisis metode kuadran, hanya Kabupaten Badung yang masuk di kuadran I. Seluruh daerah non-SDA masuk di kuadran II, sementara keseluruhan daerah penghasil SDA masuk di kuadran III minus Kabupaten Indragiri Hilir. Di dalam kuadran IV, dari seluruh lokus penelitian hanya ada Kabupaten Indragiri Hilir. Berdasarkan hasil tersebut, pemerintah wajib memfokuskan kebijakan Transfer ke Daerah kepada daerah-daerah yang berada kuadran IV sehingga ke depannya mereka dapat melakukan berbagai perbaikan menuju kondisi yang lebih baik.

Kata Kunci: Penghasil SDA, metode kuadran, share, growth
\end{abstract}

JEL Classification: H53, Q18 


\section{PENDAHULUAN}

Di dalam Savitry (2013) diuraikan cara menganalisis pelaksanaan otonomi daerah melalui pemetaan kemampuan keuangan antardaerah. Melalui pemetaan tersebut, daerah dapat dilihat kesiapannya dalam menjalankan kewenangan yang dilimpahkan. Berdasarkan Samora (2010), pendekatan ini secara tidak langsung juga bermanfaat untuk menilai seberapa kuat penciptaan aspek kemandirian daerah yang menjadi dasar penetapan strategi pengembangan sektor-sektor potensial. Jika dikaitkan dengan aspek kemandirian, reformasi birokrasi terkait kebijakan otonomi daerah sudah berkembang secara dinamis mulai dari Undang-Undang (UU) Nomor 22 Tahun 1999 Tentang Pemerintahan Daerah hingga terakhir UU Nomor 23 Tahun 2014 Tentang Pemerintahan Daerah. Sementara itu, UU Nomor 25 Tahun 1999 juga mengalami perubahan menjadi UU Nomor 33 Tahun 2004 Tentang Perimbangan Keuangan Antara Pemerintah Pusat dan Pemerintahan Daerah (Rampengan, dkk., 2016).

Sayangnya, upaya penciptaan kemandirian daerah tersebut masih menghadapi beberapa kendala. Hasil penelitian Setiaji \& P.H. Adi (2007) menyebutkan implementasi pelaksanaan desentralisasi fiskal justru meningkatkan kadar ketergantungan fiskal daerah terhadap pemerintah pusat sebagai wujud ketidakberdayaan Pendapatan Asli Daerah (PAD) dalam membiayai belanja daerahnya. Penelitian lainnya oleh Susanto (2014), Widodo (2011) kemudian Herawati \& Supratiwi (2013), secara rata-rata menggambarkan lemahnya kemandirian daerah serta tingginya ketergantungan terhadap bantuan pusat.

Rendahnya kemandirian tersebut bahkan secara merata terjadi juga di Kawasan Timur Indonesia (KTI). Penelitian Pilat \& Jenny Morasa (2017) misalnya menyimpulkan bahwa pola hubungan tingkat kemandirian Kota Manado masih sangat rendah untuk pelayanan sosial kemasyarakatan. Pola hubungan dengan pemerintah pusat juga bersifat instruktif, begitu halnya Susanto (2014) dan Dethan (2015) terkait dengan lokus penelitian yang sama yaitu Provinsi Nusa Tenggara Barat (NTB). Hasil yang sedikit berbeda diutarakan oleh Ulumudin (2014) yang menilai evaluasi kinerja keuangan daerah seKaresidenan Pekalongan tahun 2007-2011. Dalam kesimpulannya, Ulumudin menyebutkan bahwa di Kabupaten Pemalang, Kabupaten Tegal, Kota Tegal, Kabupaten Batang, dan Kota Pekalongan ternyata memiliki indeks kemampuan keuangan daerah yang tinggi. Hanya Kabupaten Brebes dan Kabupaten Pekalongan yang kondisi kemampuan keuangan daerahnya relatif masih rendah.
Terdapat beberapa faktor penyebab utama rendahnya kemandirian daerah: 1) rendahnya potensi PAD daerah bersangkutan; atau 2) beban belanja APBD yang relatif besar di era desentralisasi fiskal (Hidayat, dkk., 2016). Perlu diingat bahwa Indonesia melaksanakan asas desentralisasi fiskal dari aspek belanja tidak seperti praktek desentralisasi di beberapa negara lainnya yang merujuk pada aspek penerimaan, karena masih adanya mekanisme Transfer ke Daerah (Krisztina, Kis Kastos \& Bambang Suharnoko Sjahrir, 2014). Jadi otonomi daerah di Indonesia adalah otonomi belanja APBD secara mandiri seiring dengan penyerahan kewenangan dari pemerintah pusat, meskipun dilihat dari aspek ketatanegaraan daerah merupakan subordinat dari pemerintah pusat (Muin, 2014).

Untuk itulah pengelolaan belanja APBD yang lebih rasional dan bersifat investasi produktif menjadi aspek utama peningkatan kemandirian di daerah (Sudaryanti, 2013), meskipun tidak dapat dipungkiri bahwa peran anggaran operasional khususnya belanja pegawai masih signifikan memengaruhi kinerja organisasi pemerintahan dan birokrasi (Magno dkk., 2015). Dalam bahasa lainnya, merujuk penelitian Fatoni \& Indah Dewi Nurhayati (2013), efisiensi belanja daerah tersebut merupakan parameter utama dari pencapaian aspek kemandirian di daerah melalui penciptaan anggaran partisipatif yang mendukung kinerja aparatur. Anggaran partisipatif adalah anggaran yang disusun dengan melibatkan peran serta pegawai secara optimal serta berorientasi kepada pencapaian kinerja (Usman \& Selmita Paranoan, 2013).

Kondisi daerah-daerah di Indonesia yang sangat bervariasi juga menjadi pendorong isu kemandirian daerah. Beberapa daerah diklasifikasikan sebagai daerah penghasil SDA. Sebagian lagi, diklasifikasikan sebagai daerah non-SDA, tetapi masih memiliki basis penerimaan perpajakan yang tak kalah besarnya. Sayangnya, mayoritas daerah lainnya justru tidak memiliki kekayaan SDA maupun basis pajak yang memadai (Feryawan, 2011). Untuk daerah-daerah yang tidak memiliki kekayaan SDA maupun basis pajak, seharusnya menjadi target utama pemerataan pemerintah melalui alokasi Transfer ke Daerah.

Karakteristik daerah-daerah penghasil SDA dan daerah-daerah non-SDA jelas sangat berbeda. Begitupula perbandingan peta kemampuan keuangan daerahnya. Namun demikian, penelitian yang mencoba membandingkan peta kemampuan keuangan daerah penghasil SDA dan non-SDA belum banyak dilakukan. Padahal, bagi pemerintah analisis ini menjadi penting untuk menetapkan pola strategi pengembangan ekonomi ke depannya. Untuk itulah penelitian ini kemudian mencoba menjawab 
kebutuhan analisis perbandingan peta kemampuan keuangan daerah penghasil SDA dengan daerah nonSDA.

Sebagai sebuah karya tulis, penelitian ini masih mengandung beberapa keterbatasan penelitian. Keterbatasan penelitian yang pertama adalah unsur analisis di dalam kajian hanya memfokuskan kepada aspek-aspek keuangan daerah semata. Beberapa variabel yang sifatnya non keuangan seperti leadership pimpinan daerah, partisipasi publik, tidak menjadi dasar analisis di dalam kajian ini. Keterbatasan penelitian berikutnya terkait dengan ketersediaan data. Data yang digunakan adalah data realisasi APBD tahun 2010 hingga 2014, sebagai data terkini yang sudah mendapat pengesahan dari BPK. Data APBD tahun 2015 sebetulnya sudah didapatkan, namun belum dilakukan verifikasi atas validitas datanya sehingga penulis tidak menggunakan data APBD tahun 2015 tersebut.

Mendasarkan kepada teori Musgrave (1989), disebutkan adanya 3 peran dari pemerintah yaitu peran alokasi, peran distribusi dan stabilisasi. Peran alokasi sangat dikaitkan dengan adanya kebijakan APBN sebagai politik anggaran pemerintah untuk memberikan alokasi anggaran yang nantinya diharapkan dapat berfungsi sebagai stimulus dalam perekonomian. Peran alokasi ini juga dikaitkan dengan adanya kewajiban pemerintah untuk menyediakan dan mengalokasikan barang publik kepada masyarakat secara umum. Sementara peran distribusi sangat erat dengan peran pemerintah untuk tetap menjaga alur distribusi baik pendapatan maupun hal lainnya dalam menjaga kerangka pemerataan dan keadilan. Yang terakhir adalah peran stabilisasi yang memerlukan adanya keterlibatan pemerintah di dalam menjaga aspek stabilisasi nasional dari segala sektor.

Pelaksanaan desentralisasi fiskal dan otonomi daerah dapat menjawab keseluruhan peran dari pemerintah tersebut. Dengan mengalokasikan Transfer ke Daerah maka jelas kewajiban pemerintah telah dilaksanakan secara nyata dan menyeluruh. Bagaimana pemerintah menyusun kebijakan Transfer ke Daerah dalam rangka menjaga aspek pemerataan antara daerah dan wilayah mencerminkan pelaksanaan peran distribusi. Beberapa kebijakan ad hoc yang bersifat penyeimbang dalam kerangka hubungan Transfer ke Daerah menjawab tuntutan peran stabilisasi pemerintah.

Otonomi daerah merupakan bentuk nyata dari pelaksanaan teori kebijakan publik secara nyata khususnya jika dikaitkan dengan reformasi manajemen keuangan daerah. Di dalam era transisi otonomi daerah, beberapa permasalahan masih sering dijumpai diantaranya belum mantapnya perangkat hukum, kelembagaan, infrastruktur serta sumber daya manusia (SDM). Otonomi daerah sering dipandang sebagai realisasi nyata dari ideide desentralisasi. Mendasarkan kepada penelitian Rinaldi (2012) daerah otonom merupakan wujud nyata dan dianutnya asas devolusi serta dekonsentrasi sebagai makna dari desentralisasi sendiri. Karenanya otonomi harus dipahami secara fungsional dengan orientasi kepada upaya memaksimalkan fungsi pemerintahan agar dapat dilakukan secepat, sedekat, dan setepat mungkin dengan kebutuhan masyarakat. Penelitian lainnya juga menyebutkan bahwa otonomi merupakan suatu keadaan tidak bergantung kepada siapa pun atau secara populis dapat dimaknai sebagai kewenangan yang dimiliki daerah untuk mengatur sistem administrasi birokrasi, keuangan serta kebijakan publiknya dalam batasan-batasan yang telah ditetapkan dan disepakati bersama (Hruza, 2015). Royani (2012) menambahkan bahwa dengan adanya otonomi daerah tersebut maka sebuah pembangunan yang lebih terarah dan tepat sasaran akan diwujudkan.

Dalam kajian Sasana (2015), pengembangan otonomi pada level daerah kabupaten dan kota seharusnya diselenggarakan dengan lebih memerhatikan prinsip-prinsip demokrasi, peran serta masyarakat, pemerataan, dan keadilan serta memerhatikan potensi keanekaragaman daerah. Sementara itu, berdasarkan UU Nomor 23 Tahun 2014, yang dimaksud dengan desentralisasi fiskal adalah penyerahan sumber-sumber pembiayaan fiskal kepada daerah seiring dengan penyerahan Urusan Pemerintahan oleh Pemerintah Pusat kepada daerah otonom berdasarkan Asas Otonomi. Sedangkan otonomi daerah sendiri dijabarkan sebagai hak, wewenang, dan kewajiban daerah otonom untuk mengatur dan mengurus sendiri Urusan Pemerintahan dan kepentingan masyarakat setempat dalam sistem Negara Kesatuan Republik Indonesia (NKRI).

Pembagian Urusan Pemerintahan didasarkan kepada filosofi pembagian masing-masing kewilayahan tersebut, memiliki kewajiban untuk meningkatkan efisiensi dan efektivitas penyelenggaraan pemerintahan serta pelayanan kepada masyarakat (Mahmudi, 2010). Karenanya antara pemerintah pusat dan pemerintah daerah harus melaksanakan hubungan keuangan, pelayanan umum serta pemanfaatan SDA dan sumber daya lainnya secara adil dan selaras berdasarkan regulasi. Kerangka otonomi daerah dan desentralisasi fiskal ini kemudian memberikan dimensi yang lebih jelas bagi daerah dalam menyelenggarakan pemerintahan dan pelayanan serta pengelolaan keuangan berdasarkan prinsip transparansi, partisipasi, dan akuntabilitas. 
Urusan pemerintahan yang menjadi kewenangan pusat didanai dengan APBN sementara urusan pemerintahan yang menjadi kewenangan daerah didanai dengan APBD (Soleh \& Suripto, 2011).

Namun demikian, untuk beberapa urusan yang bersifat mutlak dalam rangka penyediaan pelayanan yang berskala nasional (lintas provinsi) maka pemerintah dapat melimpahkan kepada Gubernur melalui mekanisme pendanaan dekonsentrasi atau tugas pembantuan jika dilimpahkan kepada Bupati/ Walikota. Kedua sumber pendanaan ini berasal dari mekanisme penganggaran di Kementerian/ Lembaga $(K / L)$ teknisnya serta tidak masuk di dalam APBD karena yang bertanggung jawab adalah pemerintah pusat (Nanda \& Darwanis, 2016). Untuk menyelenggarakan urusan yang sudah menjadi kewenangan daerah, sumber-sumber pendanaan yang dapat dikelola oleh APBD terdiri dari PAD, Dana Perimbangan, Pinjaman Daerah, dan Lain-lain PAD yang Sah (Basri, dkk., 2013).

PAD bertujuan untuk mendanai pelaksanaan otonomi daerah sesuai dengan perwujudan desentralisasi serta bersumber dari pajak daerah, retribusi daerah, hasil pengelolaan kekayaan daerah yang dipisahkan serta lain-lain PAD yang sah. Sementara Dana Perimbangan terdiri dari Dana Bagi Hasil (DBH), Dana Alokasi Umum (DAU), dan Dana Alokasi Khusus (DAK). Dilihat dari mekanismenya, DBH dan DAU adalah dana block grants yang dialokasikan untuk tujuan mengurangi kesenjangan vertikal dan horizontal. Sementara DAK adalah dana APBN yang bersifat khusus untuk mendukung pembangunan di daerah yang belum dapat dipenuhi dari alokasi DAU (Muryawan \& Made Sukarsa, 2014).

Adanya mekanisme hubungan perimbangan keuangan antara pemerintah pusat dan pemerintahan daerah tersebut merupakan hal yang sangat urgent. Perjalanan penerapan desentralisasi fiskal dari masa ke masa pada periode sebelumnya, memberikan pembelajaran bahwa pola-pola dan sistem yang bersifat sentralistik dapat mengakibatkan munculnya in-efficiency dan high cost economy dalam penyediaan sarana dan prasarana pengembangan ekonomi daerah serta iklim investasi yang kondusif (Kemenkeu, 2012).

Mekanisme perimbangan keuangan antara pemerintah pusat dan pemerintahan daerah juga ditujukan untuk mengubah pendulum yang awalnya bersifat sangat sentralistik menuju pola hubungan yang lebih terdesentralisasi (Pratikno, 2005). Di dalam pola hubungan yang sentralistik ini, pemerintah pusat akan sangat mendominasi segala hubungan dari segi pemerintahan. Perencanaan dan pengendalian yang terpusat mengharuskan adanya sistem organisasi pemerintahan dan manajemen proyek yang dikembangkan di daerah dengan harapan hasilnya mudah diukur, dikendalikan, diawasi serta dievaluasi (Rasyid, 2002). Pembagian kewenangan serta tersedianya ruang gerak yang memadai untuk memaknai kewenangan yang diberikan kepada unit pemerintahan yang lebih rendah merupakan pembeda utama diantara keduanya (Sabeni \& Imam Ghozali, 1995).

Oleh Litvack \& Seddon (1999), desentralisasi dapat diartikan sebagai sebuah penyerahan kewenangan dan tanggung jawab dari pemerintah pusat kepada pemerintah daerah atau pihak-pihak unit organisasi lainnya termasuk swasta. Hal ini mengindikasikan bahwa penyerahan kewenangan tersebut juga diikuti dengan proses penyerahan sumber-sumber pembiayaan sesuai dengan prinsip money follows function, meskipun Rondinelli, dkk. (1983) hanya menekankan desentralisasi sebagai sebuah proses transfer kekuatan politik semata sementara Leemans (1970) membedakan menjadi representative local government dan field administration.

Menurut Halim (2007) yang dimaksud dengan keuangan daerah adalah semua hak dan kewajiban yang dapat dinilai dengan uang serta segala sesuatu baik berupa barang yang dapat dijadikan kekayaan daerah, sepanjang hal tersebut belum dimiliki atau dikuasai oleh negara atau daerah yang lebih tinggi kedudukannya sesuai dengan peraturan yang berlaku. Sementara berdasarkan UU Nomor 23 Tahun 2014 Tentang Pemerintahan Daerah, yang disebut dengan keuangan daerah adalah semua hak dan kewajiban yang dapat dinilai dengan uang dan segala sesuatu berupa barang dan uang yang dapat dijadikan milik daerah yang berhubungan dengan pelaksanan hak dan kewajiban tersebut. Di dalam penjelasan pasal 4 Peraturan Pemerintah Nomor 105 Tahun 2000, ditegaskan bahwa manajemen keuangan daerah harus dilakukan secara tertib, taat pada regulasi, efisien, efektif, transparan, dan bertanggungjawab dengan memerhatikan asas keadilan (Kuncoro, 2004).

Dalam Mahmudi (2010), dijelaskan bahwa reformasi manajemen keuangan daerah di Indonesia dikatakan cukup terlambat jika dibandingkan beberapa negara lainnya. Bahkan jika dibandingkan dengan negara-negara tetangga lainnya seperti Malaysia, Filipina, dan Singapura serta Selandia Baru, sudah sejak akhir tahun 1970an dan 1980an melakukan rangkaian reformasi di bidang manajemen keuangan publik. Penganggaran berbasis kinerja misalnya, Singapura sudah menjalankan sejak awal 1980an, sementara di Indonesia baru diperkenalkan tahun 2001. Namun demikian perjalanan reformasi manajemen keuangan di Indonesia boleh dikatakan 
termasuk yang paling progresif kemajuannya (Yatiman \& Arif Pujiyono, 2013).

Reformasi manajemen keuangan daerah di dalam (Policy Brief Kemenkeu, 2012) dianggap memiliki hubungan sebab akibat yang signifikan dengan implementasi kebijakan otonomi daerah tersebut. Perbaikan manajemen keuangan daerah akan mendukung keberhasilan kebijakan otonomi daerah dan sebaliknya otonomi daerah yang konsisten akan mendorong terjadinya perubahan manajemen keuangan daerah. Terlebih apabila dikaitkan dengan perubahan paradigma pencapaian tujuan pembangunan di daerah dari yang semula bersifat makro ekonomi semata (first fundamental theory of welfare economics) menuju pencapaian tujuan pembangunan daerah yang berimbang (second fundamental theory of welfare economics) (Sagala \& Parmadi, 2013).

Diskusi mengenai manajemen daerah juga terkait erat dengan penilaian kinerja pengelolaan keuangan daerah. Untuk mengukur penilaian kinerja pengelolaan keuangan daerah itu sendiri, digunakan beberapa pendekatan yang berbasis rasio-rasio keuangan daerah sebagai gambaran pertanggungjawaban APBD terhadap kewenangan yang dilimpahkan (Efendi \& Sri Wuryanti, 2011). Secara lebih mendalam, menurut (Sundari \& Suprantiningrum, 2015) hasil analisis rasio-rasio ini nantinya bertujuan untuk: 1) menilai kemandirian keuangan daerah dalam membiayai pelaksanaan otonomi daerah; 2) mengukur efektivitas dan efisiensi realisasi pendapatan daerah; 3) mengukur efektivitas pemerintah daerah dalam membelanjakan pendapatan daerahnya; 4) mengukur kontribusi dari masing-masing sumber pendapatan dalam pembentukan pendapatan daerah; serta 5) melihat perkembangan perolehan pendapatan dan pengeluaran yang dilakukan dalam periode waktu tertentu.

Adapun rasio-rasio keuangan daerah yang sering digunakan dalam analisis kemampuan keuangan daerah, dalam Yuana (2014) diantaranya rasio kemandirian keuangan daerah, rasio efektivitas $P A D$, rasio efisiensi $P A D$, rasio Indeks Kemampuan Rutin (IKR) serta Indeks Harmonisasi Belanja (IHB). Meskipun sudah menjadi pemahaman bersama, beberapa pihak ternyata masih belum sepakat dengan rasio-rasio yang disusun tersebut. Mereka beranggapan bahwa penggunaan rasio-rasio tersebut layak hanya untuk sektor swasta. Sementara di sektor pemerintah masih mengandung beberapa kelemahan khususnya terkait dengan keterbatasan penyajian laporan keuangan daerah, penyusunan APBD masih berdasarkan pertimbangan incremental budget dan penilaian keberhasilan APBD dalam pertanggungjawaban pengelolaan keuangan daerah lebih ditekankan kepada aspek pencapaian target tanpa memerhatikan perubahan komposisi atau struktur APBD (Rustan, 2013).

\section{METODE}

Metodologi penelitian yang digunakan di dalam kajian ini termasuk dalam metode penelitian deskriptif. Metodologi penelitian tersebut dipilih mengingat peneliti bermaksud mengumpulkan berbagai informasiaktual secara rinciyang melukiskan gejala yang ada terkait dengan aspek kemandirian dan ketergantungan daerah melalui indikator share dan growth. Kemudian dilakukan sebuah prosedur identifikasi masalah atau memeriksa kondisi dan praktek-praktek yang berlaku sekaligus membuat perbandingan antara daerah penghasil SDA dan nonSDA. Adapun rekomendasi yang nantinya dihasilkan akan dijadikan dasar rujukan di dalam pengambilan sebuah kebijakan dengan mendasarkan kepada fenomena yang terjadi di level implementasi.

Dengan demikian, penggunaan metode penelitian deskriptif ini nantinya sangat bermanfaat sebagai sarana melukiskan secara sistematis fakta atau karakteristik daerah penghasil SDA dan nonSDA untuk dihasilkan sebuah rekomendasi kebijakan pemerintah. Terkait dengan pendekatan penelitian, kajian ini menggunakan pendekatan kuantitatif berupa indikator rasio share dan growth untuk masing-masing karakteristik daerah baik penghasil SDA dan non-SDA. Adapun tujuan yang diharapkan adalah tergambarnya secara deskriptif indikator share dan growth tersebut ke dalam masing-masing karakteristik daerah sehingga dapat dilihat analisis perbandingannya.

Pemilihan indikator share dan growth yang dikombinasikan dalam metode kuadran, sering digunakan oleh pemerintah untuk melakukan analisis perbandingan kinerja publik khususnya terkait dengan pelaksanaan desentralisasi fiskal (Bappenas, 2003). Penggunaan metode kuadran ini, sering disebut sebagai salah satu upaya terbaik untuk menampilkan peta kemampuan keuangan daerah melalui aspek nilai besaran share atau kontribusi pendapatan daerah terhadap total belanja APBD serta nilai growth untuk melihat pertumbuhan komponen pendapatan daerah dalam APBD. Dengan analisis share dan growth maka potensi pengembangan ekonomi di daerah diharapkan dapat tergambarkan dan pemerintah juga dapat mengambil kebijakan yang sesuai dengan karakteristik masing-masing daerah.

Indikator share ini bertujuan untuk melihat seberapa besar kontribusi pendapatan APBD 
terhadap total belanja daerah dan berfungsi sebagai proxy dari aspek kemandirian daerah, sementara indikator growth digunakan untuk melihat potensi pertumbuhan APBD ke depannya. Indikator share dihitung berdasarkan rasio sebagai berikut:

$$
\begin{aligned}
& \text { Share }=\frac{(P A D+D B H)}{\text { Total belanja }} \times 100 \% \\
& \text { Di mana: } \\
& \text { PAD : Pendapatan Asli Daerah } \\
& \text { DBH : Dana Bagi Hasil (Pajak dan SDA) } \\
& \text { Total Belanja : Belaja dalam APBD }
\end{aligned}
$$

Sementara itu indikator rasio growth dihitung berdasarkan rasio:

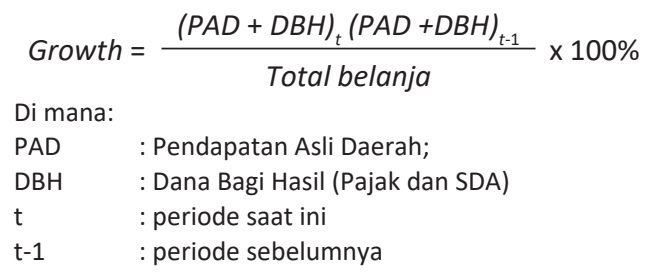

Jenis data yang diolah di dalam kajian ini adalah jenis data sekunder yang diperoleh dari lembaga resmi pemerintah dalam hal ini adalah Direktorat Jenderal Perimbangan Keuangan(DJPK), Kementerian Keuangan. Metode analisis yang digunakan adalah metode kuadran yang akan membagi daerah menjadi 4 kuadran dengan karakteristik masing-masing. Adapun pembagian kuadran dan pemaknaannya sebagai berikut:

a. Kuadran I: merupakan kuadran paling ideal, sebagai hasil gabungan antara daerah dengan karakteristik share dan growth yang tinggi. Daerah-daerah yang masuk kuadran I ini dikategorikan sebagai daerah mandiri dan berpotensi;

b. Kuadran II: merupakan kuadran yang menggambarkan kondisi belum ideal, namun daerah memiliki kemampuan untuk mengembangkan potensi lokalnya sehingga PAD berpeluang mengambil peran yang besar dalam membiayai total belanja. Karakteristik daerah dengan rasio share tinggi, namun growth-nya rendah. Kondisi ini mengindikasikan daerahdaerah yang masuk dalam status tidak mandiri namun berpotensi;

c. Kuadran III: merupakan kuadran yang juga belum ideal. Peran PAD, DBH relatif besar terhadap total belanja, namun berpeluang untuk terus mengalami penurunan karena pertumbuhannya mengecil. Kondisi ini mengindikasikan daerahdaerah yang mandiri namun kurang berpotensi;

d. Kuadran IV: merupakan kuadran yang paling tidak ideal karena menggambarkan karakteristik daerah dengan share rendah dan growth yang lemah. Artinya PAD dan $\mathrm{DBH}$ belum memiliki peran yang besar dalam membiayai total belanja APBD-nya. Kondisi ini juga menggambarkan status tidak mandiri dan kurang berpotensi;

Untuk lokus perbandingan, di dalam kajian ini dicoba untuk melihat karakteristik dari daerah-daerah penghasil SDA dan non-SDA. Untuk mempermudah analisis, definisi dan pemilihan daerah penghasil SDA dan non-SDA didasarkan kepada hasil penelitian (Martawardaya, dkk., 2015) yang membagi daerahdaerah yang memiliki kekayaan SDA serta dianggap menjadi daerah penghasil seperti Kabupaten Indragiri Hilir, Kabupaten Kampar, Kabupaten Siak, Kabupaten Bengkalis, Musi Rawas, Musi Banyuasin, Bojonegoro, Kutai Kertanegara, Kota Baru, dan Kutai Barat (Martawardaya, dkk., 2015). Sebagai sebuah hasil kajian, penelitian yang dilakukan oleh (Martawardaya, dkk, 2015) cukup komprehensif untuk dijadikan dasar rujukan di dalam penelitian ini.

$\mathrm{Hal}$ tersebut didasarkan kepada validitas data yang digunakan, kelengkapan indikator, metodologi penelitian yang dipakai sekaligus permasalahan yang dianalisis terkait dengan fenomena kutukan SDA di daerah. Pertama-tama ditetapkan karakteristik data DBH migas secara nasional. Daerah yang memiliki alokasi DBH migas di atas rata-rata nasional kemudian dijadikan sampel daerah. Untuk menganalisis terjadinya fenomena kutukan SDA di daerah, data DBH migas disandingkan dengan beberapa data dan indikator pembanding lainnya seperti IPM, kemiskinan, tingkat pendidikan, dan pengangguran. Terlihat bahwa daerah dengan alokasi DBH migas besar tidak menjamin adanya kinerja kesejahteraan masyarakat yang memadai sehingga dianalogikan bahwa fenomena kutukan SDA memang terbukti.

Karena dalam penelitian ini akan dibandingkan daerah penghasil dengan non-penghasil, maka peneliti juga melakukan klasifikasi daerah penghasil $\mathrm{DBH}$ pajak yang tinggi secara nasional. Dari hasil analisis, daerah-daerah yang memiliki alokasi DBH Pajak yang berada di atas rata-rata nasional yaitu Kota Medan, Kota Bandung, Kota Bekasi, Kota Tangerang, Kota Surabaya, dan Kabupaten Badung.

\section{HASIL DAN PEMBAHASAN}

Secara keseluruhan, hasil analisis dan pembahasan kajian akan dibedakan ke dalam analisis share, analisis growth, dan analisis gabungan dalam metode kuadran. Penjelasan lebih lanjut dapat diuraikan sebagai berikut:

\section{Analisis Share}

Berdasarkan hasil perhitungan, dapat diketahui bahwasanya nilai share dari daerah-daerah 
penghasil SDA dalam kurun waktu 2010-2014 lebih tinggi secara rata-rata dibandingkan nilai share dari daerah-daerah non-SDA, kecuali Kabupaten Badung yang memilki share rata-rata 88,47.

Di antara keseluruhan daerah penghasil SDA, Kabupaten Bengkalis tercatat memiliki nilai share yang paling besar dengan rata-rata selama 5 tahun mencapai nilai 105,89. Hanya di tahun 2013, nilai share Kabupaten Bengkalis di bawah nilai 100. Bahkan di tahun 2010, Kabupaten Bengkalis tercatat memiliki nilai share terbesar hingga mencapai 125,28. Daerah berikutnya yang tercatat memiliki nilai share relatif besar adalah Kabupaten Kutai Kertanegara sebesar 98,70 dan disusul berikutnya oleh Kabupaten Siak dengan ratarata 93,49, dan Kabupaten Musi Banyuasin sebesar 93,29 . Sementara Kabupaten Kota Baru dan Kabupaten Bojonegoro tercatat memiliki nilai share paling rendah, masing-masing sebesar 33,74 dan 40,21.

Dengan merujuk kepada perhitungan nilai share yang didapat dengan pembilangnya adalah total belanja daerah, maka hipotesis paling valid daerah-daerah penghasil SDA secara rata-rata memiliki share yang tinggi adalah kemampuan mengelola belanja APBD dalam batas rasionalitas. Terlebih Kabupaten Bengkalis, Kabupaten Kutai Kertanegara, Kabupaten Siak, dan Musi
Banyuasin adalah beberapa kabupaten hasil pemekaran daerah. Karenanya manajemen pengelolaan belanja APBD, sekiranya menjadi prasyarat wajib di dalam upaya mewujudkan APBD yang handal, transparan, dan berdaya, baik bagi peningkatan pelayanan publik, pembangunan daerah serta pertumbuhan ekonomi. Sementara, Kabupaten Bojonegoro dan Kabupaten Kota Baru adalah contoh kabupaten lama yang sudah mapan, namun justru mengalami permasalahan di dalam manajemen pengelolaan APBD dari sisi belanja.

Untuk kasus daerah non-SDA, secara keseluruhan menunjukkan pola yang hampir sama dengan kasus Kabupaten Bojonegoro dan Kota Baru, karena memang daerah-daerah tersebut adalah daerah-daerah lama yang sudah terbangun dari periode sebelum pelaksanaan desentralisasi fiskal dan otonomi daerah. Kecuali Kabupaten Badung, hampir seluruh daerah lokus kajian di non-SDA nilai share-nya di bawah 50 . Kota Surabaya boleh dilihat sebagai salah satu daerah potensial selain Kabupaten Badung dengan nilai share sebesar 57,05, setelah memperlihatkan peningkatan yang stabil sejak tahun 2012 hingga 2014. Kota Bekasi bahkan tercatat memilki nilai share terendah dalam kurun 2010-2014 hanya mencapai 38,44. Keseluruhan hasil analisis dapat dilihat pada Tabel 1 .

Tabel 1. Nilai Perbandingan Share Daerah Penghasil dan Non-SDA

\begin{tabular}{|c|c|c|c|c|c|c|}
\hline Nama Daerah & 2010 & 2011 & 2012 & 2013 & 2014 & Rerata \\
\hline Kab. Indragiri Hilir & 63,72 & 50,84 & 47,85 & 38,17 & 39,93 & 48,10 \\
\hline Kab. Kampar & 70,34 & 60,19 & 70,60 & 60,89 & 63,39 & 65,08 \\
\hline Kab. Siak & 101,69 & 111,81 & 93,26 & 80,72 & 79,96 & 93,49 \\
\hline Kab. Bengkalis & 125,28 & 116,92 & 107,04 & 78,97 & 101,24 & 105,89 \\
\hline Kab. Musi Rawas & 54,59 & 49,93 & 52,66 & 46,16 & 46,80 & 50,03 \\
\hline Kab. Musi Banyuasin & 109,41 & 81,35 & 83,09 & 118,92 & 73,69 & 93,29 \\
\hline Kab. Bojonegoro & 34,20 & 40,08 & 43,94 & 37,80 & 45,03 & 40,21 \\
\hline Kab. Kutai Kertanegara & 107,65 & 125,31 & 108,68 & 67,90 & 83,98 & 98,70 \\
\hline Kab. Kota Baru & 26,25 & 33,45 & 37,53 & 35,05 & 36,44 & 33,74 \\
\hline Kab. Kutai Barat & 65,66 & 65,91 & 67,40 & 47,71 & 46,06 & 58,55 \\
\hline Kota Medan & 43,08 & 41,75 & 44,49 & 42,80 & 41,18 & 42,66 \\
\hline Kota Bandung & 37,14 & 38,63 & 41,60 & 41,43 & 44,13 & 40,59 \\
\hline Kota Bekasi & 34,77 & 37,98 & 39,51 & 36,92 & 43,02 & 38,44 \\
\hline Kota Tangerang & 39,93 & 46,02 & 49,17 & 41,55 & 54,63 & 46,26 \\
\hline Kab. Tangerang & 34,12 & 43,51 & 41,19 & 46,14 & 48,96 & 42,78 \\
\hline Kota Surabaya & 45,14 & 56,50 & 60,43 & 60,56 & 62,64 & 57,05 \\
\hline Kab. Badung & 88,38 & 97,30 & 87,10 & 84,77 & 84,82 & 88,47 \\
\hline Mean & 63,61 & 64,56 & 63,27 & 56,85 & 58,58 & 61,37 \\
\hline Min & 26,25 & 33,45 & 37,53 & 35,05 & 36,44 & 26,25 \\
\hline Max & 125,28 & 125,31 & 108,68 & 118,92 & 101,24 & 125,31 \\
\hline
\end{tabular}

Sumber: DJPK, Kemenkeu, Data diolah. 
Dengan melihat analisis berdasarkan Tabel 1 tersebut, dapat terlihat bahwa daerah-daerah penghasil SDA secara karakteristik memiliki nilai share yang lebih tinggi dibandingkan daerah-daerah nonSDA. Dengan demikian daerah-daerah penghasil SDA sebetulnya memiliki peluang untuk menjadi daerah dengan kemandirian yang besar dalam menjalankan kewenangan urusannya sendiri di era desentralisasi fiskal. Manajemen pengelolaan belanja APBD yang rasional tentu menjadi prasyarat utamanya. Jika dikaitkan dengan sifat dari kekayaan SDA yang tidak dapat diperbaharui, maka daerah-daerah penghasil SDA sudah selayaknya mulai memikirkan shifting sektoral dengan menggunakan kekayaan SDA yang saat ini masih melimpah. Jangan sampai proses peralihan sektoral ini terlambat dan dilakukan ketika daerah sudah mengalami kemunduran dalam produksi kekayaan SDA-nya. Di banyak negara dan daerah, teori kutukan SDA banyak dijumpai dan terbukti ketika negara atau daerah yang memiliki kekayaan SDA tersebut justru menjadi negara atau daerah yang pertama kali mengalami kebangkrutan.

Untuk daerah-daerah yang masuk kategori non-SDA, ke depannya perlu memikirkan untuk mengkaji ulang besaran total belanja APBD yang lebih rasional. Hal ini perlu dilakukan mengingat dalam periode 2010-2014, secara rata-rata daerahdaerah non-SDA masuk dalam kategori share rendah. Jika pola ini diteruskan, bukan tidak mungkin ke depannya nilai share daerah akan terus menurun seiring dengan peningkatan beban belanja APBD. Kota Bekasi contohnya, nilai share yang dihasilkan setiap tahunnya tidak pernah lebih besar dari 40 . Padahal dengan melihat posisi sebagai daerah penyangga ibu kota negara, Kota Bekasi seharusnya mampu tumbuh lebih cepat dan besar dibandingkan pencapaian saat ini. Jika peningkatan PAD secara spektakuler agak terkendala, satu-satunya cara yang paling mungkin ditempuh adalah reformasi manajemen belanja APBD. Secara bertahap daerah harus mampu mengurangi belanja-belanja yang bersifat administratif rutin belaka. Di sisi lainnya, terus diperbanyak alokasi belanja yang bersifat investasi serta memiliki daya ungkit yang besar bagi tumbuhnya sektor-sektor lainnya.

\section{Analisis Growth}

Jika di dalam analisis share dapat disimpulkan bahwa daerah-daerah penghasil SDA memiliki nilai yang lebih besar dibandingkan daerah-daerah nonSDA, maka di dalam analisis growth pencapaiannya justru terbalik. Daerah-daerah non-SDA justru memiliki nilai growth yang lebih tinggi dibandingkan daerah-daerah penghasil SDA. Di dalam kelompok daerah non-SDA, Kabupaten Tangerang memiliki nilai growth yang paling besar yaitu 32,70 dalam kurun 2010-2014. Disusul kemudian oleh tetangganya, Kota Tangerang sebesar 27,12, dan Kota Bekasi sebesar 25,02. Cukup menarik jika melihat komposisi ini mengingat dari sisi share, tiga besar daerah nonSDA ini masuk dalam kategori rendah dan sedang.

Namun demikian, dengan hasil temuan ini justru memperkuat indikasi bahwa Kabupaten Tangerang, Kota Tangerang, dan Kota Bekasi memiliki share yang kecil, semata-mata disebabkan oleh manajemen pengelolaan belanja APBD yang kurang manageable. Sementara dari sisi pertumbuhan APBD-nya, daerahdaerah tersebut masih dapat terus berkembang ke depannya. Temuan menarik lainnya adalah masuknya Kabupaten Badung ke dalam daerah dengan kategori growth APBD relatif rendah, hanya 24,50. Padahal dilihat dari sisi nilai share, Kabupaten Badung layak bersaing dengan daerah-daerah mandiri lainnya. Termasuk juga kasus yang terjadi di Kabupaten Bojonegoro. Dari nilai share, Kabupaten Bojonegoro digolongkan ke dalam daerah yang kurang mandiri, namun dari sisi nilai growth justru sangat tinggi mencapai 31,47. Hasil analisis perbandingan growth daerah penghasil dan non-SDA dapat dilihat pada Tabel 2.

Meskipun sedikit bervariasi jika dibandingkan analisis share, boleh disimpulkan bahwa berdasarkan nilai growth maka daerah-daerah non-SDA memiliki karakteristik lebih tinggi dibandingkan daerahdaerah penghasil SDA. Hipotesis yang mungkin dapat menjelaskan fenomena ini adalah keterkaitannya dengan dampak multiplier yang dihasilkan. Dengan mendasarkan kepada analisis input-output, industri berbasis SDA diketahui merupakan salah satu industri yang memiliki daya konsentrasi besar serta tidak berkelanjutan. Berbeda dengan daerahdaerah non-SDA yang biasanya berbasis industri jasa yang memiliki daya tumbuh lebih lama serta mampu membangkitkan industri lainnya baik dari sisi hulu maupun hilir. Dan hal ini sudah diterapkan di Kabupaten Bojonegoro di mana kekayaan SDA nya digunakan untuk mengembangkan industri kreatif pariwisata berbasis tambang, UMKM serta pembentukan Dana Abadi Migas. Dengan demikian, rekomendasi untuk segera melaksanakan proses shifting industri di daerah penghasil SDA, sepertinya menjadi kewajiban yang tak dapat ditawar lagi.

\section{Analisis Metode Kuadran}

Dari hasil analisis share dan growth, keseluruhan daerah sebagai lokus penelitian kemudian disandingkan dan dipetakan ke dalam analisis metode kuadran yang akan membagi menjadi empat kuadran. Dari hasil 
Tabel 2. Nilai Perbandingan Growth Daerah Penghasil dan Non-SDA

\begin{tabular}{|c|c|c|c|c|c|}
\hline Nama Daerah & 2011 & 2012 & 2013 & 2014 & Rerata \\
\hline Kab. Indragiri Hilir & 3,90 & $-22,14$ & 19,56 & 17,69 & 4,75 \\
\hline Kab. Kampar & 1,84 & 14,94 & 1,63 & 22,98 & 10,35 \\
\hline Kab. Siak & $-4,67$ & 17,36 & $-5,41$ & 15,87 & 5,79 \\
\hline Kab. Bengkalis & 30,28 & 3,45 & $-11,00$ & 23,27 & 11,50 \\
\hline Kab. Musi Rawas & 0,59 & 14,87 & 5,01 & $-15,43$ & 1,26 \\
\hline Kab. Musi Banyuasin & 5,04 & 21,13 & $-59,69$ & 24,66 & $-2,21$ \\
\hline Kab. Bojonegoro & 36,95 & 44,08 & 3,36 & 41,49 & 31,47 \\
\hline Kab. Kuta Kertanegara & 18,10 & 9,24 & -6.67 & 7,94 & 7,15 \\
\hline Kab. Kota Baru & 26,36 & 26,17 & 16,26 & 22,88 & 22,92 \\
\hline Kab. Kutai Barat & 17,36 & 26,08 & $-11,36$ & $-26,98$ & 1,27 \\
\hline Kota Medan & 31,84 & 5,88 & 2,68 & 11,09 & 12,87 \\
\hline Kota Bandung & 27,00 & 22,01 & 14,92 & 17,33 & 20,31 \\
\hline Kota Bekasi & 35,83 & 31,23 & 10,67 & 22,35 & 25,02 \\
\hline Kota Tangerang & 35,08 & 25,75 & 21,43 & 26,22 & 27,12 \\
\hline Kab. Tangerang & 55,08 & 26,46 & 35,50 & 13,74 & 32,70 \\
\hline Kota Surabaya & 29,18 & 22,49 & 17,89 & 16,73 & 21,57 \\
\hline Kab. Badung & 31,22 & 32,91 & 14,89 & 18,98 & 24,50 \\
\hline Mean & 22,41 & 18,94 & 4,10 & 15,34 & 15,20 \\
\hline Min & $-4,67$ & $-22,14$ & $-59,69$ & $-26,98$ & $-28,37$ \\
\hline Max & 55,08 & 44,08 & 35,50 & 41,49 & 44,04 \\
\hline
\end{tabular}

Sumber: DJPK, Kemenkeu, data diolah.

pemetaan dapat dilihat analisis ke dalam Diagram 1 dengan penjelasan sebagai berikut;

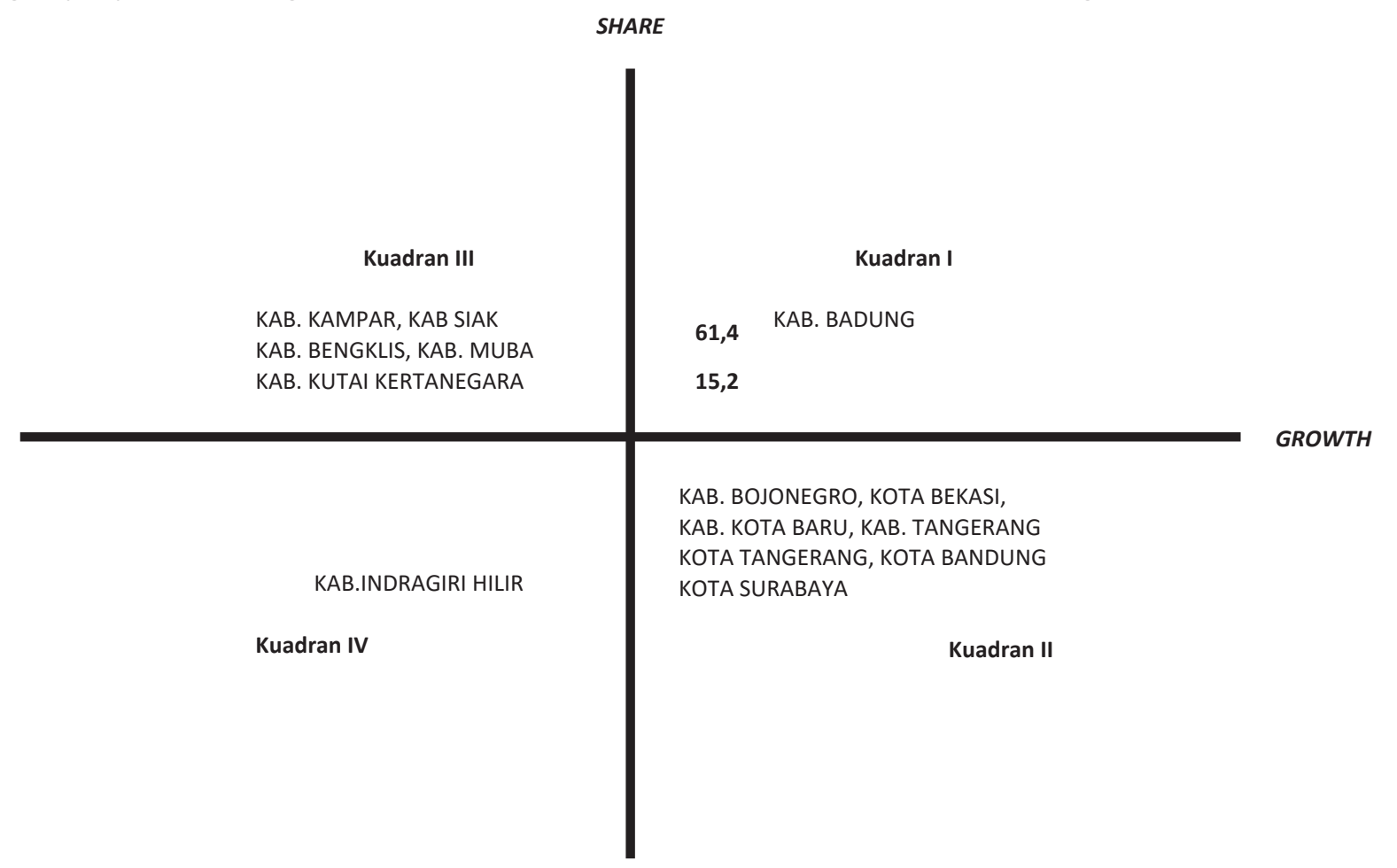

a. Kuadran I: hanya Kabupaten Badung yang masuk ke dalam kategori daerah di kuadran I.

Diagram 1. Pemetaan Analisis Kuadran Daerah Penghasil dan Non-SDA 
Artinya Kabupaten Badung merupakan satusatunya daerah ideal dengan nilai share dan growth paling tinggi diantara keseluruhan lokus penelitian lainnya. Hal ini juga menggambarkan bahwa kemandirian daerah di Kabupaten Badung relatif tinggi dengan prospek perkembangan ekonomi yang masih positif. Pemerintah Kabupaten Badung wajib mempertahankan pencapaian ini dibarengi dengan penyusunan strategi pengembangan periode berikutnya, mengingat dari hasil analisis parsial nilai growth, Kabupaten Badung termasuk kategori rendah. Berbagai kebijakan dan pungutan yang sekiranya kontra produktif dengan semangat pengembangan sektor-sektor pendukung harus segera direformasi sebelum menjadi hambatan yang bersifat struktural;

b. Kuadran II: keseluruhan daerah non-SDA masuk di dalam kategori kuadran II, ditambah dengan Kabupaten Bojonegoro. Dengan demikian daerah non-SDA dianggap tidak memiliki kemandirian yang memadai namun punya potensi pertumbuhan yang besar. Rendahnya aspek kemandirian daerah non-SDA lebih disebabkan beban pengelolaan belanja daerah yang besar. Mengingat tantangan pertumbuhan ekonomi yang semakin besar ke depannya terlebih dari sisi eksternal, bagi daerah-daerah yang masuk dalam ketegori kuadran II ini sepertinya perlu untuk mengambil kebijakan radikal di dalam pengelolaan manajemen belanja APBD. Kebijakan tersebut dapat berupa penghematan belanja di daerah atau reformasi penguatan belanja-belanja yang bersifat produktif dan menumbuhkan dampak bagi sektor-sektor lainnya;

c. Kuadran III: keseluruhan daerah penghasil SDA masuk di dalam kategori kuadran III minus Kabupaten Indragiri Hilir. Dengan masuk kategori kuadran III, artinya daerah-daerah penghasil SDA memiliki share yang tinggi namun growth-nya kecil atau dimaknai sebagai daerah yang cukup mandiri namun kurang berpotensi. Seperti yang sudah dibahas sebelumnya, growth yang kecil disebabkan sifat dari industri berbasis SDA yang tidak berkelanjutan serta tidak memiliki daya ungkit besar baik industri hulu dan hilirnya. Untuk itu wajib bagi daerah-daerah penghasil SDA untuk segera keluar dari jebakan SDA, mulai mengembangkan industri lainnya dengan menggunakan kekayaan SDA sebagai investasi pengembangan. Hal ini makin menjadi kewajiban jika dikaitkan dengan isu berlakunya teori kutukan SDA. Daerah-daerah penghasil SDA juga sudah memiliki modalitas aspek kemandirian yang bagus khususnya dari sisi manajemen pengelolaan belanja APBD, sehingga hanya perlu meningkatkan nilai growth;

d. Kuadran IV: di dalam kategori ini hanya ada Kabupaten Indragiri Hilir dari keseluruhan lokus penelitian. Kuadran IV ini sejujurnya adalah kategori daerah yang paling tidak ideal karena didefinisikan sebagai daerah dengan nilai share dan growth yang rendah. Kebijakan Transfer ke Daerah sepertinya perlu diarahkan untuk menyasar daerah-daerah yang masuk kuadran IV seperti ini sehingga ke depannya dalam melakukan lompatan masuk ke kuadran lainnya yang lebih bermakna positif. Pilihan kebijakannya dapat melalui perbaikan manajemen pengelolaan belanja APBD, ataupun kebijakan shifting sektoral di daerah dengan perubahan paradigma kekayaan SDA dijadikan investasi pengembangan tidak untuk sekedar dinikmati semata;

\section{KESIMPULAN}

Pemetaan kemampuan keuangan daerah digunakan sebagai alat ukur kesiapan daerah dalam menjalankan kewenangannya. Pemetaan juga dijadikan dasar strategi pengembangan sektor potensial di daerah dalam mendorong kemandirian. Sayangnya, dalam banyak kasus, rendahnya kemandirian daerah di era desentralisasi fiskal lebih disebabkan oleh beban belanja APBD yang besar. Untuk itu diperlukan perubahan pola pengelolaan belanja APBD yang rasional dan bersifat investasi produktif dalam mendorong kemandirian. Indonesia juga memiliki banyak karakteristik daerah. Beberapa daerah dapat dikategorikan sebagai daerah penghasil SDA, sebagian lagi dikategorikan daerah non-SDA dengan basis penerimaan pajak yang besar. Sayangnya, mayoritas daerah lainnya di Indonesia justru tidak memiliki keduanya.

Dalam perspektif pemerintah penting untuk melihat perbedaan karakteristik di daerah penghasil SDA dan non-SDA tersebut sebagai dasar pengambilan kebijakan pembangunan secara nasional. Sayangnya, penelitian yang menjelaskan perbedaan karakteristik daerah penghasil SDA dan non-SDA basis pajak belum terlalu banyak. Karenanya penelitian ini kemudian dilakukan untuk memberikan masukan bagi pemerintah dalam menganalisis karakteristik masingmasing. Penelitian dilakukan dengan menggunakan analisis metode kuadran yang diturunkan ke dalam besaran nilai share dan growth dari masing-masing daerah.

Besaran nilai share untuk menggambarkan potensi kemandirian di daerah sedangkan 
nilai growth ditujukan untuk melihat potensi pertumbuhan ekonomi ke depannya. Dari hasil analisis parsial indikator share dapat dilihat bahwa daerah-daerah penghasil SDA memilki angka yang lebih besar dibandingkan daerah non-SDA. Kabupaten Bengkalis tercatat memiliki nilai share terbesar mencapai 105,89, disusul Kabupaten Kutai Kertanegara, Kabupaten Siak, dan Kabupaten Musi Banyuasin sebesar 93,29.

Sebaliknya, dari hasil analisis parsial nilai growth, keseluruhan daerah non-SDA justru memiliki nilai lebih besar dibandingkan daerah-daerah penghasil. Kabupaten Tangerang memiliki nilai growth tertinggi 32,70 dalam kurun 2010-2014. Disusul kemudian oleh tetangganya, Kota Tangerang dan Kota Bekasi. Sementara daerah-daerah penghasil SDA secara ratarata memiliki growth yang rendah, kecuali Kabupaten Bojonegoro yang memiliki nilai growth 31,47. Tingginya growth Kabupaten Bojonegoro merupakan dampak positif berbagai upaya alih industri dari yang awalnya berbasis SDA menuju non-SDA.

Dengan menggunakan analisis metode kuadran, hanya Kabupaten Badung yang masuk ke dalam kategori daerah di kuadran I dengan nilai share dan growth paling tinggi diantara keseluruhan lokus penelitian lainnya. Hal ini juga menggambarkan bahwa kemandirian daerah di Kabupaten Badung relatif tinggi dengan prospek perkembangan ekonomi yang masih positif. Keseluruhan daerah non-SDA masuk di dalam kategori kuadran II, ditambah dengan Kabupaten Bojonegoro. Masuknya seluruh daerah non-SDA ke dalam kuadran II ini artinya daerahdaerah tersebut memiliki prospek pertumbuhan ekonomi yang bagus ke depannya, namun nilai share yang kecil akibat beban pengelolaan belanja daerah yang besar.

Keseluruhan daerah penghasil SDA masuk di dalam kategori kuadran III minus Kabupaten Indragiri Hilir. Dengan masuk kategori kuadran III, artinya daerah-daerah penghasil SDA memiliki share yang tinggi namun growth nya kecil. Seperti yang sudah dibahas sebelumnya, growth yang kecil disebabkan sifat dari industri berbasis SDA yang tidak berkelanjutan serta tidak memiliki daya ungkit besar baik industri hulu dan hilirnya. Untuk itu wajib bagi daerah-daerah penghasil SDA untuk segera keluar dari jebakan SDA, mulai mengembangkan industri lainnya.

Di dalam kuadran IV, hanya ada Kabupaten Indragiri Hilir dari keseluruhan lokus penelitian. Kuadran IV ini adalah kategori daerah yang paling tidak ideal karena didefinisikan sebagai daerah dengan nilai share dan growth yang rendah. Kebijakan Transfer ke Daerah sepertinya perlu diarahkan untuk menyasar daerah-daerah yang masuk kuadran IV seperti ini sehingga ke depannya dalam melakukan lompatan masuk ke kuadran lainnya yang lebih bermakna positif.

Dengan melihat berbagai kesimpulan dari hasil analisis, pemerintah perlu penguatan kebijakan untuk mengevaluasi pelaksanaan desentralisasi fiskal dan otonomi daerah. Sebagai input kebijakan dapat berdasarkan temuan hasil hasil kajian ini misalnya untuk daerah penghasil SDA, ternyata secara umum memiliki kemandirian daerah yang tinggi namun nilai pertumbuhan ekonomi ke depannya rendah. Artinya perlu dipikirkan sebuah kebijakan dalam rangka mendukung upaya hijrah sektoral di daerah dari yang awalnya berbasis SDA menuju non-SDA dengan tetap menjaga manajemen pengelolaan belanja APBD yang rasional.

Sebaliknya, untuk daerah-daerah non-SDA ternyata memiliki kemandirian daerah rendah, namun pertumbuhan ekonomi ke depannya positif dan tinggi. Karenanya perlu kebijakan reformasi manajemen pengelolaan belanja APBD untuk lebih memprioritaskan belanja-belanja yang bersifat produktif dan investasi. Rekomendasi ini mungkin menjadi hal yang lebih berat untuk dilakukan pemerintah pusat mengingat kesepakatan pelaksanaan desentralisasi fiskal dan otonomi daerah di Indonesia yang menganut pola otonomi dari sisi belanja. Pemerintah pusat mungkin dapat memulai dari beberapa kewenangan yang bersifat lintas dan mendasar terkait pelayanan publik, pembangunan daerah, dan pertumbuhan ekonomi.

Bagi para akademisi dan perguruan tinggi sekiranya juga dapat mendukung berbagai upaya yang sedang menjadi pekerjaan besar pemerintah pusat dalam menciptakan pola desentralisasi fiskal dan otonomi daerah yang lebih efisien dan efektif. Perlu diingat bahwa aspek manajemen pengelolaan belanja daerah yang berkualitas dapat dimulai dari exercise di level akademik, dan di saat bersamaan perguruan tinggi juga dapat meningkatkan kemampuan dan kualitas Sumber Daya Manusia (SDM) dari aparat pemerintah daerah masingmasing. 


\section{DAFTAR PUSTAKA}

\section{Buku}

Musgrave, Richard A Musgrave, Peggy B. (1989). Public finance in theory and practise. Mc Graw Hill Book Company.

Halim, Abdul. (2007). Akuntansi keuangan daerah. Jakarta: Penerbit Salemba Empat.

Kuncoro, Mudrajat. (2004). Otonomi dan pembangunan daerah: Reformasi, perencanaan, strategi dan peluang. Yogyakarta: Penerbit Erlangga.

Kementerian Keuangan. (2012). Pelengkap buku pegangan penyelenggaraan pemerintahan dan pembangunan daerah. Jakarta: Direktorat Jenderal Perimbangan Keuangan. Kemenkeu; Jakarta.

Kementerian Keuangan. (2012).Policy brief 2012. Tim Asistensi Kementerian Keuangan Bidang Desentralisasi Fiskal. Jakarta.

Leemans, AF. (1970). Changing patterns of local government. Netherlands: The Hague.

Mahmudi. (2010). Manajemen keuangan daerah. Jakarta: Penerbit Erlangga.

Martawardaya, Berly, dkk (2015). Kutukan sumber daya alam di tingkat kabupaten/kota di Indonesia. Jakarta: Article 33 Indonesia.

Pratikno. (2005). Exercising freedom local autonomy and democracy in Indonesia, 1999-2001, in Erb, Maribeth et.al (eds.) Regionalism in Post Soeharto Indonesia. New York: Routledge Curzon.

Rasyid. Ryaas. (2002). Menolak resentralisasi pemerintahan. Jakarta: Publisher PT. Dyatama Milenia.

Soleh, Chabib \& Suripto. (2011). Menilai kinerja pemerintahan daerah. Jakarta: Penerbit Fokusmedia.

Sabeni, Arifin \& Imam Ghozali. (1995). Pokok-pokok akuntansi pemerintahan. Yogyakarta: Penerbit BPFE.

\section{Jurnal dan Working Paper}

Bappenas. (2003). Peta kemampuan keuangan daerah provinsi dalam era otonomi daerah: tinjauan kinerja PAD dan upaya yang dilakukan daerah. Direktorat Pengembangan Otonomi Daerah.
Basri, Hasan.dkk, (2013). Pemetaan kinerja pendapatan asli daerah dan kemampuan keuangan daerah kabupaten/kota di Provinsi Jambi. Jurnal . Vol. 30. No.1.

Dethan, Stevany Hanalyna. (2015). Analisis kemampuan keuangan daerah pada kabupaten/ kota di Provinsi NTB tahun anggaran 2009-2013. Jurnal Ganesha Swara.Vol. 9. No. 2.

Efendi, David \& Sri Wuryanti. (2011). Analisis perkembangan kemampuan keuangan daerah dalam mendukung pelaksanaan otoda di Kabupaten Nganjuk. Seminar Nasional IImu Ekonomi Terapan. FE UNIMUS.

Feryawan, D. Y. (2011). Assessing natural resources curse hypothesis at the local level in Indonesia: the evidence of the missing money. Graduate School of Development Studies. Institute of Social Studies. The Hague. The Netherlands.

Fatoni, Irfan \& Indah Dewi Nurhayati. (2013). Pengaruh anggaran dan pengendalian terhadap efektifitas kinerja SKPD di Kabupaten Malang. Jurnal Manajemen dan Akuntansi. Vol. 2 No. 3.

Herawati, Nunik Retno \& Supratiwi. (2013). Optimalisasi pajak daerah dalam rangka meningkatkan kemampuan keuangan daerah. Jurnal IImu Sosial. Vol. 12. No. 1.

Hruza, Filip. (2015). Public sector organization financial ratios recent development as a matter of financial innovation. Investment Management and Financial Innovations. Vol. 12, Issue 2.

Hidayat, Muhammad. dkk. (2016). Analisis kemampuan keuangan kabupaten/kota di Provinsi Sumatera Barat dalam era otonomi daerah. Jurnal Sungkai. Vol. 4. No. 2.

Krisztina, Kis Kastos \& Bambang Suharnoko Sjahrir. (2014). The impact of fiscal and political decentralization on local public investment in Indonesia. Discussion Paper No. 7884.IZA, Germany.

Litvack, J. \& Jessica Seddon, (1999). Decentralization briefing notes. The World Bank. Washington DC.

Muin, Fatkhul. (2014). Otonomi daerah dalam perspektif pembagian urusan pemerintahpemerintah daerah dan keuangan daerah. Fiat Justisia. Jurnal IImu Hukum. Vol. 8. No. 1.

Magno, Ruivo Barros. dkk. (2015). Pengaruh pengelolaan anggaran terhadap kinerja organisasi pemerintahan. REFORMASI. Vol. 5. No. 2. 
Muryawan, Sang Made \& Made Sukarsa. (2014). Pengaruh desentralisasi fiskal, fiscal stress dan kinerja keuangan daerah terhadap pertumbuhan ekonomi di kabupaten/kota Provinsi Bali. E-Jurnal Ekonomi Pembangunan. Vol. 3. No.10.

Nanda, Reza \& Darwanis. (2016). Analisis implementasi anggaran berbasis kinerja pada pemerintah daerah. Jurnal Ilmiah Mahasiswa Ekonomi Akuntansi. Vol. 1. No.1.

Pratikto, A. (2002). Dampak alokasi pengeluaran investasi di Provinsi DKI Jakarta terhadap kinerja perekonomian daerah.Tesis Master Ekonomi. Program Pascasarjana, Universitas Indonesia, Jakarta.

Pilat, Juddy Julian \& Jenny Morasa. (2017). Analisis rasio keuangan anggaran APBD Kota Manado untuk menilai kinerja keuangan pemerintah Kota Manado tahun anggaran 2011-2015. Jurnal Accountability. Vol. 06. No.01.

Rondinelli, Dennis A, dkk. (1983). Decentralization in developing countries: A review of recent experience. Management and Development Series No. 8. The World Bank. Washington DC.

Rinaldi, Udin (2012). Kemandirian keuangan dalam pelaksanaan otonomi daerah. Jurnal Kebijakan dan Administrasi Publik. Vol. 8. No. 2.

Royani, Ida (2012). Analisis kemampuan keuangan daerah dalam mendukung pelaksanaan otonomi daerah di Kabupaten Ponorogo dan Madiun tahun anggaran 2008-2010. Skripsi. Jurusan Akuntansi FE. Universitas Muhammadiyah Ponorogo.

Rustan. (2013). Desentralisasi fiskal dan pertumbuhan ekonomi serta kaitannya dengan otonomi daerah. Jurnal Borneo Administrator. Vol. 9. No. 3.

Rampengan, Melania. dkk (2016). Analisis efektifitas dan efisiensi pelaksanaan anggaran belanja Bappeda Kota Manado. Jurnal Berkala Ilmiah Efisiensi. Vol. 16. No. 03.

Setiaji, W \& P.H. Adi. (2007). Peta kemampuan keuangan daerah sesudah otonomi daerah: apakah mengalami pergeseran (studi empiris pada kabupaten dan kota se-Jawa-Bali). Makalah. Simposium Nasional Akuntansi X. Universitas Hasanudin.

Samora, Ramon. (2010). Peta kemampuan keuangan daerah pada pemerintahan kota dan kabupaten se-Jawa dan Bali tahun 2004-2008: Metode kuadran. Jurnal Akuntansi Kontemporer. Vol. 2. No. 1.
Savitry, Ermitha. (2013). Analisis kemampuan keuangan daerah dalam pelaksanaan otonomi daerah tahun 2007-2011 di Kota Makasar. Skripsi. Jurusan Ilmu Pemerintahan. Universitas Hasanudin.

Sudaryanti, Dwi. (2013). Pengaruh penganggaran terhadap kinerja aparat pemda melalui sistem informasi keuangan daerah (studi kasus: Pemda Kabupaten Kudus). Jurnal ekonomi dan Bisnis. Vol.12. No. 01.

Sagala, Lerindra M \& Parmadi. (2013). Analisis kemampuan keuangan daerah: Studi kasus Kota Jambi dan Kabupaten Batanghari. Jurnal Paradigma Ekonomika. Vol. 1. No. 7.

Susanto, Hery. (2014). Analisis kemampuan keuangan daerah pemerintah Provinsi Nusa Tenggara Barat. Jurnal Organisasi dan Manajemen. Vol. 10. No. 1.

Sasana, Hadi. (2015). Dampak implementasi desentralisasi fiskal terhadap pertumbuhan ekonomi dan stabilitas harga di provinsi di Indonesia. Media Ekonomi dan Keuangan. Vol. 30. No.1.

Widodo, Pamuji. (2011). Analisis kemampuan dan efektifitas keuangan daerah empat kabupaten di Pulau Madura dalam era otonomi daerah. Skripsi. Ilmu Ekonomi dan Studi Pembangunan. Fakultas Ekonomi. Universitas Jember.

Usman, Ernawaty \& Selmita Paranoan. (2013). anggaran pastisipatif dalam menunjung kinerja aparatur pemda.Jurnal Akuntansi Multiparadigma. Vol. 4. No. 1.

Ulumudin, Ikhya. (2014). Evaluasi kinerja keuangan daerah se-Karesidenan Pekalongan tahun 2008-2011. Skripsi. Program Studi Ekonomi Pembangunan. Fakultas Ekonomi dan Bisnis. Universitas Muhammadiyah Surakarta.

Yatiman, Nur \& Arif Pujiyono. (2013). Analisis efisiensi teknis anggaran belanja sektor kesehatan pemerintah daerah kabupaten/kota di Provinsi DIY tahun 2008-2010. Diponegoro Journal of Economics. Vol. 2. No. 1.

Yuana, Alfionita Putri. (2014). Analisis kinerja keuangan daerah terhadap pertumbuhan ekonomi dan ketimpangan regional di era desentralisasi fiskal: Studi kabupaten/kota di Provinsi Jawa Timur periode 2008-2012. Skripsi. Jurusan Ilmu Ekonomi. FEB Universitas Brawijaya. 
Peraturan Perundang-Undangan

Undang-Undang Nomor 22 Tahun 1999 Tentang Pemerintahan Daerah.

Undang-Undang Nomor 25 Tahun 1999 Tentang Perimbangan Keuangan Antara Pemerintah Pusat dan Daerah.

Undang-undang Nomor 34 Tahun 2000 Tentang Pajak Daerah dan Retribusi Daerah.
Undang-Undang Nomor 32 Tahun 2004 Tentang Pemerintahan Daerah.

Undang-undang Nomor 33 Tahun 2004 Tentang Perimbangan Keuangan Antara Pemerintah Pusat dan Pemerintahan Daerah.

Undang-undang Nomor 23 Tahun 2014 Tentang Pemerintahan Daerah. 